\title{
Hubungan Asupan Zat Gizi, Aktivitas Fisik, dan Persentase Lemak Tubuh dengan Kebugaran Jasmani
}

\author{
Rhosidatus Salamah $^{1^{*}}$, Apoina Kartini ${ }^{1}$, M. Zen Rahfiludin ${ }^{1}$ \\ ${ }^{1}$ Bagian Ilmu Gizi, Fakultas Kesehatan Masyarakat, Universitas Diponegoro \\ *Email: rhosidatus.salamah@gmail.com
}

Info Artikel : Diterima 21 Januari 2019 ; Disetujui 2 Maret 2019 ; Publikasi 29 April 2019

\begin{abstract}
ABSTRAK
Latar belakang: Kebugaran jasmani merupakan kemampuan individu untuk melakukan aktivitas fisik dengan mudah tanpa mengalami kelelahan yang berlebihan. Kebugaran jasmani akan menunjang kemampuan atlet namun diperlukan asupan yang memiliki kandungan zat gizi yang cukup dan seimbang. Penelitian ini bertujuan untuk mengetahui hubungan asupan zat gizi, aktivitas fisik, dan persentase lemak tubuh dengan kebugaran jasmani pada atlet taekwondo.

Metode: Jenis penelitian ini adalah explanatory research dengan pendekatan cross sectional. Populasi adalah seluruh atlet taekwondo anggota Klub HTC Central Semarang (laki-laki dan perempuan) sebanyak 50 responden. Pengambilan sampel menggunakan teknik purposive sampling, subjek sejumlah 42 orang. Bivariat dianalisis dengan menggunakan uji korelasi Pearson Product Moment dan Rank Spearman. Multivariat dianalisis menggunakan uji regresi linier dengan variabel dummy.

Hasil: Tidak ada hubungan antara tingkat konsumsi energi $(\mathrm{p}=0,528, \mathrm{r}=-0,100)$ dan tingkat konsumsi lemak $(\mathrm{p}=0,741 \mathrm{r}=0,052)$ dengan persentase lemak tubuh pada atlet taekwondo. Ada hubungan antara tingkat konsumsi energi $(\mathrm{p}=0,035 \mathrm{r}=-0,326)$ dengan kebugaran fisik pada atlet taekwondo. Tidak ada hubungan tingkat konsumsi lemak ( $\mathrm{p}=0,188 \mathrm{r}=-0,207)$. Ada hubungan antara aktivitas fisik $(\mathrm{p}=0,000 \mathrm{r}=0,822)$ dengan kebugaran fisik pada atlet taekwondo. Ada hubungan antara persentase lemak tubuh $(\mathrm{p}=0,005 \mathrm{r}=-0,422)$ dengan kebugaran fisik pada atlet taekwondo. Hasil analisis multivariat menunjukkan bahwa aktivitas fisik merupakan variabel yang paling berhubungan dengan kebugaran jasmani atlet taekwondo.

Simpulan: Penelitian ini merekomendasikan agar atlet dapat meningkatkan asupan energi guna mencukupi kebutuhan atlet, serta kebugaran
\end{abstract}

Kata kunci: Asupan Zat Gizi, Aktivitas Fisik, Persentase Lemak Tubuh, Kebugaran Jasmani, Atlet Taekwondo

\section{ABSTRACT}

Title:Correlations Between Nutritional Intake, Physical Activity and Body Fat Percentage with Physical Fitness

Background: Physical Fitness is the ability of individuals to carry out physical activity easily without experiencing excessive success. To support Athlet's ability to have good physical fitness, intake is needed which has adequate and balanced nutrition. This study aimed to analyze the correlation of nutrient intake, physical activity, and body fat percentage with physical fitness in taekwondo athletes.

Method: This was an explanatory research with a cross sectional approach. The population was all taekwondo athletes members of the HTC Central Semarang Club (50 subjects). Forty-two subjects were selected by purposive sampling. Bivariate analysis using correlation Pearson and Rank Spearman test. Multivariate analysis using linear Regression Test with Dummy Variable.

Result: There were no correlation between level energy consumption $(p=0.528, r=-0.100)$ and level of fat consumption $(p=0.741, r=0.052)$ with body fat percentage in taekwondo athletes. There was correlation between level energy consumption $(p=0.035, r=-0.326)$ and physical fitness in taekwondo athletes. There were no correlation between level of fat consumption $(p=0.188) r=-0.207)$ and physical fitness in taekwondo athletes. There was correlation between physical activity $(p=0.000 \mathrm{r}=0.822)$ and physical fitness in taekwondo athletes. There was correlation between body fat percentage $(p=0.005 r=-0.422)$ and physical fitness in taekwondo athletes. The results of multivariate analysis showed that physical activity was the variable that was most related to the physical fitness in taekwondo athletes.

Conclusion: This study recommended athletes to increase their energy in order to fulfill their nutritional needs, and improve their physical fitness.

Keywords: Nutritional Intake, Body Fat Percentage, Physical Activity, Physical Fitness, Taekwondo Athlete 


\section{PENDAHULUAN}

Olahraga adalah aktivitas fisik yang dilakukan secara berkala untuk meningkatkan kualitas kesehatan individual, kebugaran jasmani dan mencegah penyakit. ${ }^{1}$ Olahraga pada hakikatnya memanfaatkan aktivitas fisik untuk menghasilkan perubahan holistik dalam kualitas individu, baik dalam hal fisik, mental, maupun emosional. Taekwondo merupakan salah satu cabang yang banyak diminati, seni olahraga bela diri ini yang awal mulanya dikembangkan di Korea 120 abad yang lalu. Olahraga ini memiliki teknik dominan, identik dengan tendangan dan pukulan tangan kosong. Taekwondo berhubungan langsung dengan keahlian yang membutuhkan kelincahan, kecepatan, dan kekuatan. ${ }^{2}$

Menciptakan prestasi atlet yang tinggi memerlukan kebugaran jasmani dan stamina tubuh yang baik. ${ }^{3}$ Kebugaran Jasmani ialah kemampuan individu untuk melakukan aktivitas fisik dengan mudah tanpa mengalami kelelahan yang berlebihan. ${ }^{4}$

Kebugaran jasmani yang baik dapat menunjang kemampuan atlet, diperlukan asupan yang memiliki kandungan zat gizi yang cukup dan seimbang. ${ }^{3}$ Kebugaran jasmani juga berpengaruh terhadap status gizi. Status gizi harus seimbang agar tidak terjadi ganguan pertumbuhan atau perkembangan karena dalam melakukan aktivitas memerlukan energi yang di dapatkan dari makanan yang mengandung nilai gizi yang baik dan cukup. Pengaturan kecukupan gizi dapat meningkatkan keIentukan, daya tahan otot, koordinasi dan kelincahan gerak. ${ }^{5}$ Pemberian makanan juga harus memperhatikan jenis kelamin, usia, berat badan, aktivitas serta jenis olahraga yang ditekuninya. ${ }^{6}$ Salah satu klub taekwondo di Semarang ialah Hwarang Tae Kwon Do CIub (HTC). Setiap tahunnya HTC Central mengadakan tes kebugaran jasmani dengan mengukur $\mathrm{VO}_{2} \max$ para atlet. Dari hasil pengukuran $\mathrm{VO}_{2}$ max tahun 2017 diketahui, dari 30 atlet kyorugi terdapat 9 atlet yang kebugaran nya kurang yaitu $<33,8 \mathrm{mI} / \mathrm{kg} / \mathrm{mnt}$. Dalam tahun-tahun terakhir prestasi atlet juga tidak didapatkan adanya peningkatan prestasi yang cukup berarti.

Penelitian ini dilakukan untuk mengetahui hubungan asupan zat gizi, aktivitas fisik, dan persentase lemak tubuh dengan kebugaran jasmani.

\section{METODE PENELITIAN}

Penelitian ini bersifat explanatory research menggunakan metode survei analitik dengan rancangan penelitian Cross Sectional. Populasi pada penelitian ini adalah seIuruh atlet taekwondo usia 1318 tahun. Sampel dipilih dengan metode purposive sampling dengan perhitungan rumus lameshow, sehingga didapatkan jumlah sampel sebanyak 42 responden. Analisis yang dilakukan adalah analisis univariat, anaIisis bivariat menggunakan uji kolerasi Pearson Product Moment dan Rank Spearman dan analisis multivariat menggunakan Regresi linear Variable Dummy.
HASIL DAN PEMBAHASAN

Analisis Variabel Penelitian

Tabel 1. Rekapitulasi Hasil Univariat

\begin{tabular}{lcc}
\hline Karakteristik & \multicolumn{2}{c}{ Frekuensi } \\
\cline { 2 - 3 } Responden & N & \% \\
\hline Jenis Kelamin & & 73,8 \\
Laki-laki & 31 & 26,2 \\
Perempuan & 11 & \\
TKE & & 26,2 \\
Defisit & 11 & 21,4 \\
Kurang & 9 & 33,3 \\
Cukup & 14 & 7,1 \\
Baik & 3 & 11,9 \\
Lebih & 5 & \\
TKL & & 35,7 \\
Kurang & 15 & 35,7 \\
Baik & 15 & 28,6 \\
Lebih & 12 & \\
Aktivitas Fisik & & 45,2 \\
Ringan & 19 & 54,8 \\
Sedang & 23 & \\
Persentase Lemak Tubuh & 28,6 \\
Normal & 12 & 47,6 \\
Sedikit gemuk & 20 & 11,9 \\
Gemuk & 5 & 11,9 \\
Obesitas & 5 & \\
\hline
\end{tabular}

Berdasarkan tabel 1 menunjukkan bahwa sebagian besar responden adalah laki-laki. Tingkat konsumsi energi sebagian besar termasuk dalam kategori cukup $(33,3 \%)$. Tingkat konsumsi lemak atlet taekwondo tergolong kurang dan baik $(35,7 \%)$ Aktivitas fisik responden sebagian besar tergolong dalam kategori sedang yaitu sebanyak 23 responden $(54,8 \%)$. Sebagian besar persentase lemak tubuh responden tergolong sedikit gemuk $(47,6 \%)$.

Analisis Hubungan Variabel Terikat dengan Variabel Bebas

Tabel 2. Rekapitulasi Hasil Uji Hubungan

\begin{tabular}{lcl}
\hline \multicolumn{1}{c}{ Variabel } & $\mathbf{r}_{\mathrm{s}}$ & p value \\
\hline Tingkat Konsumsi Energi & $-0,100$ & 0,528 \\
dengan Persentase Lemak & & \\
Tubuh & &
\end{tabular}

Tingkat Konsumsi Lemak

$0,052 \quad 0,741$

dengan Persentase Lemak

Tubuh

Tingkat Konsumsi Energi $\quad-0,326 \quad 0,035^{*}$ dengan Kebugaran

Jasmani

Tingkat Konsumsi Lemak $\quad-0,207 \quad 0,188$ dengan Kebugaran

Jasmani

Persentase Lemak Tubuh $\quad-0,422 \quad 0,005^{*}$ 
dengan Kebugaran

Jasmani

Aktivitas Fisik dengan

$0,822 \quad 0,000^{*}$

Kebugaran Jasmani

*: Uji hubungan yang signifikan

Berdasarkan Tabel 2. hasil uji statistik menunjukkan hasil bahwa tidak ada hubungan tingkat konsumsi energi dengan persentase lemak tubuh $\left(p=0,741\right.$ dan $\left.r_{s}=0,052\right)$. Tidak ada hubungan tingkat konsumsi lemak dengan persentase lemak tubuh $\left(\mathrm{p}=0,052\right.$ dan $\left.\mathrm{r}_{\mathrm{s}}=-0,231\right)$. Ada hubungan tingkat konsumsi energi dengan kebugaran jasmani $(\mathrm{p}=0,035$ dan $\left.r_{s}=-0,326\right)$. Tidak ada hubungan tingkat konsumsi lemak dengan kebugaran jasmani $(\mathrm{p}=0,188$ dan $\left.r_{s}=-0,207\right)$. Ada hubungan persentase lemak tubuh dengan kebugaran jasmani $\left(\mathrm{p}=0,005\right.$ dan $\mathrm{r}_{\mathrm{s}}=$ 0,422). Ada hubungan aktivitas fisik dengan kebugaran jasmani $\left(\mathrm{p}=0,000\right.$ dan $\left.\mathrm{r}_{\mathrm{s}}=0,822\right)$.

\section{Analisis Multivariat}

Tabel 3. Hasil Analisis Multivariat

\begin{tabular}{|c|c|c|c|c|c|c|}
\hline No & Variabel & B & Beta & $p$ & $\mathrm{R}$ & $\begin{array}{c}\text { Adjusted R } \\
\text { Square }\end{array}$ \\
\hline 1 & TKE & 0,178 & 0,008 & 0,939 & \multirow{7}{*}{0,840} & \multirow{7}{*}{0,655} \\
\hline 2 & TKL & 1,022 & 0,081 & 0,421 & & \\
\hline 3 & Persentase lemak perempuan & 3,095 & 0,209 & 0,059 & & \\
\hline 4 & Persentase lemak laki-laki & 4,037 & 0,141 & 0,147 & & \\
\hline 5 & Aktivitas fisik & 6,815 & 0,558 & 0,000 & & \\
\hline \multirow[t]{2}{*}{6} & Jenis kelamin & $-4,742$ & $-0,343$ & 0,004 & & \\
\hline & Constant & 20,843 & - & 0,000 & & \\
\hline
\end{tabular}

\section{Hubungan Tingkat Konsumsi Energi dengan Persentase Lemak Tubuh}

Hasil penelitian menunjukan tidak ada hubungan antara tingkat konsumsi energi dengan persentase lemak tubuh. Berdasarkan hasil uji korelasi arah hubungan dalam penelitian ini adalah negatif. Hal ini menunjukkan bahwa apabila semakin rendahnya tingkat konsumsi energi maka semakin besar persentase lemak tubuh, ini dibuktikan dengan sebanyak 14 responden $(33,3 \%)$ atlet taekwondo dengan tingkat kecukupan energi cukup memiliki persentase lemak tubuh tergolong gemuk.

Penelitian ini sejalan dengan penelitian yang dilakukan penelitian Mira di Depok yang menyatakan bahwa tidak terdapat hubungan tingkat konsumsi energi dengan persentase lemak tubuh dengan $p=0,481(p>0,05)^{7}$

Komponen utama kesuksesan dalam olahraga dipengaruhi oleh asupan energi yang memadai guna menunjang pengeluaran kalori serta meningkatkan kekuatan, daya tahan tubuh, massa otot dan kesehatan. Jika asupan atlet tidak memadai, maka akan mempengaruhi performa atlet tersebut. Efisiensi pergerakan tubuh, intensitas dan lamanya melakukan olahraga juga mempengaruhi jumlah energi yang dibutuhkan seseorang atlet selama berolahraga. Setiap cabang olahraga memiliki kebutuhan gizi yang berbeda, namun secara umum energi merupakan zat gizi yang menjadi prioritas. ${ }^{8}$

\section{Hubungan Tingkat Konsumsi Lemak dengan Persentase Lemak Tubuh}

Hasil penelitian menunjukkan tidak ada hubungan antara tingkat konsumsi lemak dengan persentase lemak tubuh. Tingkat kecukupan lemak pada atlet taekwondo tergolong kurang dan baik. Idealnya tingkat konsumsi atlet tidak lebih dan tidak kurang, jika tingkat konsumsi lemak atlet memadai maka akan semakin menunjang pencapaian prestasi atlet. Kebutuhan zat gizi salah satunya lemak, penting dalam rangka menjaga kesehatan, adaptasi latihan dan meningkatkan stamina selama sesi latihan maupun perlombaan. ${ }^{9}$

Penelitian ini sejalan dengan penelitian yang dilakukan Mira di Depok yang menyatakan bahwa ada hubungan bermakna tingkat konsumsi lemak dengan persentase lemak tubuh dengan $\mathrm{p}=0,049$ $(\mathrm{p}<0,05) .^{7}$

Makanan berlemak memberikan sumbangan energi yang paling besar, jika simpanan energi terlalu berlebih maka akan disimpan dalam bentuk lemak dalam tubuh. Hal ini menunjukkan konsumsi makanan berpengaruh terhadap persentase lemak tubuh. ${ }^{7}$ Teori ini berbeda dengan hasil penelitian yang menunjukkan tidak terdapat hubungan tingkat konsumsi lemak dengan persentase lemak tubuh pada atlet disebabkan asupan lemak atlet rata-rata tergolong kurang. ${ }^{9}$ Tidak sejalannya dengan penelitian lainnya disebabkan oleh beberapa faktor seperti daya ingat responden, perbedaan jumlah sampel, serta perbedaan karakteristik responden seperti umur dan jenis kelamin.

\section{Tingkat Konsumsi Energi dengan Kebugaran Jasmani}

Hasil uji hubungan didapatkan hasil bahwa ada hubungan tingkat konsumsi energi dengan 
kebugaran jasmani. Hasil penelitian ini sejalan dengan penelitian oleh Intan di Jember yang menyatakan bahwa ada hubungan bermakna tingkat konsumsi energi dengan kebugaran jasmani dengan $\mathrm{p}=0,020(\mathrm{p}<0,05) .{ }^{9}$ Kesegaran jasmani seorang atlet akan baik jika tingkat konsumsi energinya cukup dan begitu pula sebaliknya. Energi dibutuhkan untuk mempertahankan hidup, menunjang pertumbuhan dan aktifitas fisik. Energi diperoleh dari karbohidrat, lemak, protein dalam suatu bahan makanan. Aktivitas fisik berat yang dijalankan oleh seorang atlet menimbulkan kecukupan zat gizi yang dalam hal ini adalah energi dan zat gizi berbeda dengan masyarakat umum. Kebugaran jasmani yang baik dapat di upayakan dengan salah satunya terpenuhinya tingkat konsumsi zat gizi yang baik. Konsumsi zat gizi baik yang sesuai dengan kebutuhan gizi akan membuat kebugaran atlet menjadi baik, sehingga menjadi tidak cepat lelah dan mampu melakukan aktivitasnya dengan baik pula sehingga mampu mencapai prestasi olahraga dengan maksimal. ${ }^{10}$

\section{Tingkat Konsumsi Lemak dengan Kebugaran Jasmani}

Hasil uji hubungan didapatkan hasil bahwa tidak ada hubungan tingkat konsumsi lemak dengan kebugaran jasmani. Hasil penelitian ini sejalan dengan penelitian Cornia di Universitas Airlangga yang menyatakan bahwa ada hubungan bermakna tingkat konsumsi lemak dengan kebugaran jasmani dengan $\mathrm{p}=0,147(\mathrm{p}>0,05)^{11}$ Lemak sebagai penghasil energi yang cukup besar namun olahragawan tidak boleh mengkonsumsi lemak secara berlebihan. Kebutuhan lemak yang dikonsumsi dalam sehari dianjurkan sebanyak $8 \%$ dari kebutuhan energi total yang berasal dari lemak jenuh kemudian 3-7\% lemak jenuh ganda. Latihan fisik dalam olahraga meningkatkan kapasitas otot dalam menggunakan lemak sebagai sumber energi. Peningkatan metabolisme lemak pada waktu melakukan kegiatan olahraga yang lama mempunyai efek melindungi pemakaian glikogen dan memperbaiki ketahanan fisik. ${ }^{12}$

\section{Hubungan Aktivitas Fisik dengan Kebugaran Jasmani}

Hasil uji hubungan didapatkan hasil bahwa ada hubungan aktivitas fisik dengan kebugaran jasmani. Aktivitas fisik dikategorikan menjadi empat yaitu aktivitas fisik sangat ringan, ringan, sedang dan berat tetapi dari hasil pengukuran dalam penelitian menunjukan bahwa responden memiliki tingkat aktivitas fisik dengan kategori sedang.

Hasil ini sejalan dengan penelitian dilakukan oleh Dinda Nurwidyastuti yang menyatakan bahwa terdapat hubungan yang bermakna antara aktivitas fisik dengan olahraga dengan kebugaran jasmani dimana nilai $\mathrm{p}=0,042 .^{13}$

Hasil penelitian ini serupa dengan teori yang ada, hal ini disebabkan karena atlet banyak melakukan aktivitas olahraga atau latihan fisik, dimana ini merupakan salah satu dari beberapa faktor yang dapat meningkatkan kebugaran jasmani, seperti faktor asupan makan, genetik, umur, jenis kelamin, dan status gizi. ${ }^{14}$

\section{Hubungan Persentase Lemak Tubuh dengan Kebugaran Jasmani}

Hasil dalam penelitian menunjukkan bahwa sebagian besar atlet taekwondo memiliki persentase lemak tubuh gemuk. Pada penelitian ini didapatkan hasil bahwa nilai koefisien korelasi negatif yang artinya bahwa semakin meningkatnya persen lemak tubuh berkolerasi negatif dengan kebugaran jasmani. Hal ini didukung oleh Refiana Putri yang menyatakan bahwa terdapat hubungan yang signifikan antara komposisi lemak tubuh dengan kebugaran jasmani mahasiswa di UKM sepakbola UNY dengan nilai $\mathrm{p}=0,004$ dan $\mathrm{r}=-0,464 .^{15}$

Hubungan persentase lemak tubuh dengan kebugaran dapat terjadi karena kelebihan lemak tubuh akan meningkatkan massa tubuh sehingga percepatan gerak menurun. Berat badan dengan komposisi lemak yang berlebih dapat menyebabkan kelelahan yang lebih cepat, oleh karena itu dengan komposisi lemak tubuh yang tinggi maka suhu tubuh akan meningkat lebih banyak sehingga tubuh akan lebih cepat lelah yang kemudian akan mempengaruhi kebugaran jasmani seorang atlet. ${ }^{15}$

\section{Variabel yang Paling Mempengaruhi \\ Kebugaran Jasmani}

Hasil analisis multivariat menunjukkan bahwa aktivitas fisik merupakan variabel yang paling mempengaruhi kebugaran jasmani atlet taekwondo. Hal ini dapat dilihat dari nilai signifikansi aktivitas fisik yaitu sebesar 0,000 yang merupakan nilai signifikansi terkecil diantara variabel yang lain. Nilai $\mathrm{R}$ sebesar 0,840 menunjukkan kolerasi hubungan kuat. Hal ini juga didukung dengan nilai koefisien determinasi (Adjusted $\mathrm{R}$ Square) menunjukkan bahwa kemampuan variabel bebas dalam menjelaskan variabel terikat (kebugaran jasmani) adalah sebesar 0,655 atau $65,5 \%$, sedangkan $34,5 \%$ adalah faktor lain yang dapat mempengaruhi kebugaran jasmani. Nilai koefisien B terbesar diantara variabel lain yaitu aktivitas fisik sebesar 6,815 yang menunjukkan tanda positif yang berarti semakin baik aktivitas fisik maka semakin baik kebugaran jasmani atlet. 


\section{SIMPULAN}

Penelitian ini menyimpulkan : 1) Tingkat konsumsi energi responden tergolong cukup $(33,3 \%)$, tingkat konsumsi lemak tergolong kurang $(35,7 \%)$ dan baik $(35,7 \%)$, persentase lemak tubuh responden tergolong gemuk $(85,7 \%)$, aktifitas fisik responden tergolong sedang $(54,8 \%)$, kebugaran jasmani responden tergolong sedang $(54,8 \%), 2)$ Tidak ada hubungan tingkat konsumsi energi dengan persentase lemak tubuh pada atlet taekwondo $(\mathrm{p}=0,528)(\mathrm{r}=-$ $0,100)$, 3) Tidak ada hubungan tingkat konsumsi lemak dengan persentase lemak tubuh pada atlet taekwondo $(\mathrm{p}=0,741)(\mathrm{r}=0,052), 4)$ Ada hubungan tingkat konsumsi energi dengan kebugaran jasmani pada atlet taekwondo $(\mathrm{p}=0,035)(\mathrm{r}=-0,326), 5)$ Tidak ada hubungan tingkat konsumsi lemak dengan kebugaran jasmani pada atlet taekwondo $(\mathrm{p}=0,188)$ $(\mathrm{r}=-0,207), 6)$ Ada hubungan persentase lemak tubuh dengan kebugaran jasmani pada atlet taekwondo $(\mathrm{p}=$ $0,005)(\mathrm{r}=-0,422), 7)$ Ada hubungan aktivitas fisik dengan kebugaran jasmani pada atlet taekwondo $(\mathrm{p}=$ $0,000)(\mathrm{r}=0,822), 8)$ Hasil analisis multivariat menunjukkan bahwa aktivitas fisik merupakan variabel yang paling berhubungan dengan kebugaran jasmani atlet taekwondo.

\section{DAFTAR PUSTAKA}

1. Toho A. Sport Development Index. Jakarta: PT. Index; 2007.

2. Kazemi M, Perri G, Soave D. A profile of 2008 Olympic Taekwondo competitors. 2010;54(C):243-9.

3. Salarkia N, Kimiagar M, Aminpour A. Food Intake, Body Composition and Endurance Capacity of National Basketball Team Players in I.R. of Iran. Med J Islam Repub Iran [Internet]. 2004;18(1):73-7. Available from: http://www.bioline.org.br/pdf?mr04012

4. Departemen Kesehatan RI. Petunjuk Teknis Pengukuran Jasmani. Jakarta: Direktorat Jenderal Bina Kesehatan Masyarakat; 2005.

5. Nurul L. Asuhan Gizi Olahraga. Yogyakarta: Rapha Publishing; 2015.

6. Maulana MA, Sulistyanto, Soni. Deskripsi Tingkat Konsumsi Energi dengan Kebugaran Jasmani (Pada Siswa Kelas V dan VI Putra SDN Pacing Kabupaten Mojokerto). J Kesehat Olahraga. 2016;

7. Heriyanto MH. Hubungan Asupan Gizi Dan Faktor Lain Dengan Persen Lemak Tubuh Pada Mahasiswi Prodi Gizi Dan Ilmu Komunikasi UI Angkatan 2009 Tahun 2012. Univ Indones. 2012;

8. Rahmawati M. Menu Tepat Makanan Atlet 11 Olahraga Terpopuler. Yogyakarta: Pustaka Baru Press; 2015.

9. Sari ID, Rohmawati N, Wahyuningtyias. Hubungan antara Tingkat Konsumsi Makanan, Suplemen dan Status Gizi dengan Tingkat Kesegaran Jasmani (Relation
Between Food Consumption, Supplement and Nutrition Status with Physical Fitness). Artik Ilm Has Penelit Mhs 2016 [Internet]. 2016; Available from: http://repository.unej.ac.id/bitstream/handle/1 23456789/78418/Intan

Dwi

Sari.pdf? sequence $=1$

10. Kartika E. Hubungan tingkat konsumsi gizi (energi, protein, besi) dan status gizi (indeks massa tubuh, kadar hemoglobin) dengan ketahanan fisik pada atlet sepak b ola di PSIS semarang tahun 2006. 2006;

11. Cornia IG, Adriani M. Hubungan antara asupan zat gizi makro dan status gizi dengan kebugaran jasmani mahasiswa UKM taekwondo. 2018;90-6.

12. Irianto D. Panduan Gizi Lengkap Keluarga dan Olahragawan. Yogyakarta: Andi Yogyakarta; 2006.

13. Nurwidyastuti D. Hubungan Konsumsi Zat Gizi, dan Faktor-faktor Lain dengan Status Kebugaran Mahasiswa Departemen Arsitektur Fakultas Teknik Universitas Indonesia Tahun 2012. Skripsi FKM Univ Indones. 2012;1-113.

14. Ridwan M, Lisnawati N, Enginelina E. Hubungan antara Asupan Energi dan Aktifitas Fisik dengan Kebugaran Jasmani. J Holist Heal Sci. 2017;1(1):1-8.

15. Sukmajati RP. Hubungan Asupan Zat Gizi Mikro Dan Komposisi Lemak Tubuh Dengan Tingkat Kebugaran Mahasiswa di UKM Sepakbola UNY. 2015; 